\title{
THE ROLE OF MONOCYTE CHEMOATTRACTANT PROTEIN-1 IN DIAGNOSIS OF ISCHEMIC HEART DISEASE WITH NEGATIVE EXERCISE
}

\author{
Adel Atia Ahmed Algdar*, Aly Mohammed Abdorahman Saad**, Islam Abdel Moneim El- \\ Sherbiny**, Ahmed Saied Eldamanhory** \\ Cardiology departments Tripoli University - Libya* \& Faculty of Medicine, Zagazig University**
}

Corresponding author

Adel Atia Ahmed Algdar dr.adelalgdar@yahoo.com
Objective: The aim of the present study was to find new simple non-invasive test can be used in early prediction of the presence of coronary artery disease. Methods: This comparative cross-sectional study was conducted at Cardiology Department, Zagazig University Hospital, and Al-Ahrar Hospital during the year period 2018.

Results: The present study was carried out among 39 patients diagnosed with ischemic heart disease (IHD) admitted at Cardiology Department, Zagazig University Hospital, and Al-Ahrar Hospital during the year period 2018. Out of total 39 patients, $51.3 \%$ were males and $48.7 \%$ were females. Conclusion: Our Study concluded that MCP-1 at cut off value $113.5 \mathrm{ng} / 1$ can predict the presence of significant coronary artery lesion need intervention in patient with chest pain and negative exercise test. Also We found that MCP-1 at cut off value $406 \mathrm{ng} / \mathrm{l}$ is correlated to heigh syntax score, that guide the decision for CABG against PCI

Key words; Monocyte Chemoattractant, Protein-1, MCP-1, Ischemic Heart Disease, Negative Exercise ECG

\section{INTRODUCTION}

T he most important cause of morbidity and mortality in the world is atherosclerotic cardiovascular disease .Symptoms and its Complications appear early before atherosclerotic cardiovascular disease (ASCVD) is diagnosed. Myocardial Infarction or death is more important clinical presentation of Coronary Artery Disease $(\mathrm{CAD})^{[1]}$.

Whereas most clinicians previously regarded atheroma as a bland lesion, the current notion that inflammation and immune response contribute to atherogenesis has garnered increased interest ${ }^{[2]}$.

Variance studies showed that the markers of inflammations such as $\mathrm{C}$ - reactive protein (CRP), Fibrinogen, Interleukin-6 (IL-6) are early predictor of cardiovascular events ${ }^{[3]}$.

Although the importance of systemic markers of inflammation, there are lake of use them as a screening method of diagnosis of $\mathrm{CAD}^{[4]}$.

MCP-1is important chemokine can be found at high levels in the patients cardiovascular diseases and MCP-1 levels decrease with treatment of CVD. It is a member from the chemokines family which is produced by endothelial cells, vascular smooth cells, keratinocytes fibroblasts, tubular epithelial cells, lymphocytes ,monocytes and macrophages, in response to the a variety proinflammatory stimuli. MCP-1 is the strongest known chemotactic factor for monocytes in $\mathrm{CVD}^{[7]}$.

\section{AIM OF THE WORK}

The aim of the present study was to find new simple non-invasive test can be used in early prediction of the presence of coronary artery disease.

\section{PATIENTS AND METHODS}

Technical design: This comparative crosssectional study was conducted at Cardiology Department, Zagazig University Hospital, and Al-Ahrar Hospital during the year period 2018. A total number of 39 consecutive patients with sympthoms of anginal pain were included in the current study.

\section{Patients were divided into two groups:}

Group I: include 25 with typical anginal pain and negative exercise test.

Group II: include 14 with typical anginal pain and positive exercise test.

\section{Inclusion criteria:}

- Patients planned for diagnostic coronary angiography; due to the presence of typical 
Adel et al...

chest pain with risk factors of IHD (DM, HTN, dyslipidemia, smokers age or family history)

\section{Exclusion criteria:}

- Patients with rheumatic heart disease;

- Patients with history of previous MI;

- Patients with history of CABG or percutaneous coronary intervention (PCI)

- Patients with chronic or acute kidney disease;

- Patients with chronic liver disease;

- Patients with poor echo window;

- Patients taking antioxidante (affecting the level of cytokines).

\section{Methods}

Our patients were subjected to the following:

1. Full history taking

2. Complete physical examination

3. Resting 12-lead surface electrocardiogram (ECG) for detecting rate, rhythm and chamber enlargement

\section{Exercise ECG Test}

Test Protocols

\section{Zagazig University Medical Journals}

The modified Bruce protocol starts off at the same speed as the Bruce protocol but with an initial grade of $0 \%$. The Cornell, Naughton, and Balke protocols use a more gradual increase in workload and are reasonable options for patients who are unable to ambulate comfortably (Franklin et al., 2000) ${ }^{10}$.

Coronary angiography analysis and detection of severity of CAD

Severity of lesion: the coronary artery narrowing was visually estimated and expressed as percentage of luminal diameter stenosis. $\mathrm{Pt}$ with $\geq 70 \%$ narrowing in LAD, circumflex artery or right coronary artery or their major branches and $\geq 50 \%$ in left main coronary were classified as having significant angiographic coronary artery disease (West et al., 1997) ${ }^{11}$.

\section{Laboratory investigation \\ Monocyte Chemoattractant Protien-1}

Quantitative measurement of Monocyte Chemoacttractant Protien-1 (MCP-1) in serum was carried out using a sensitive competitive Enzyme Linked Immunosorbent Assay (ELISA) (Elabscience Biotechnology Co. Japan).

Table 1 Demographic data of the two studied groups:

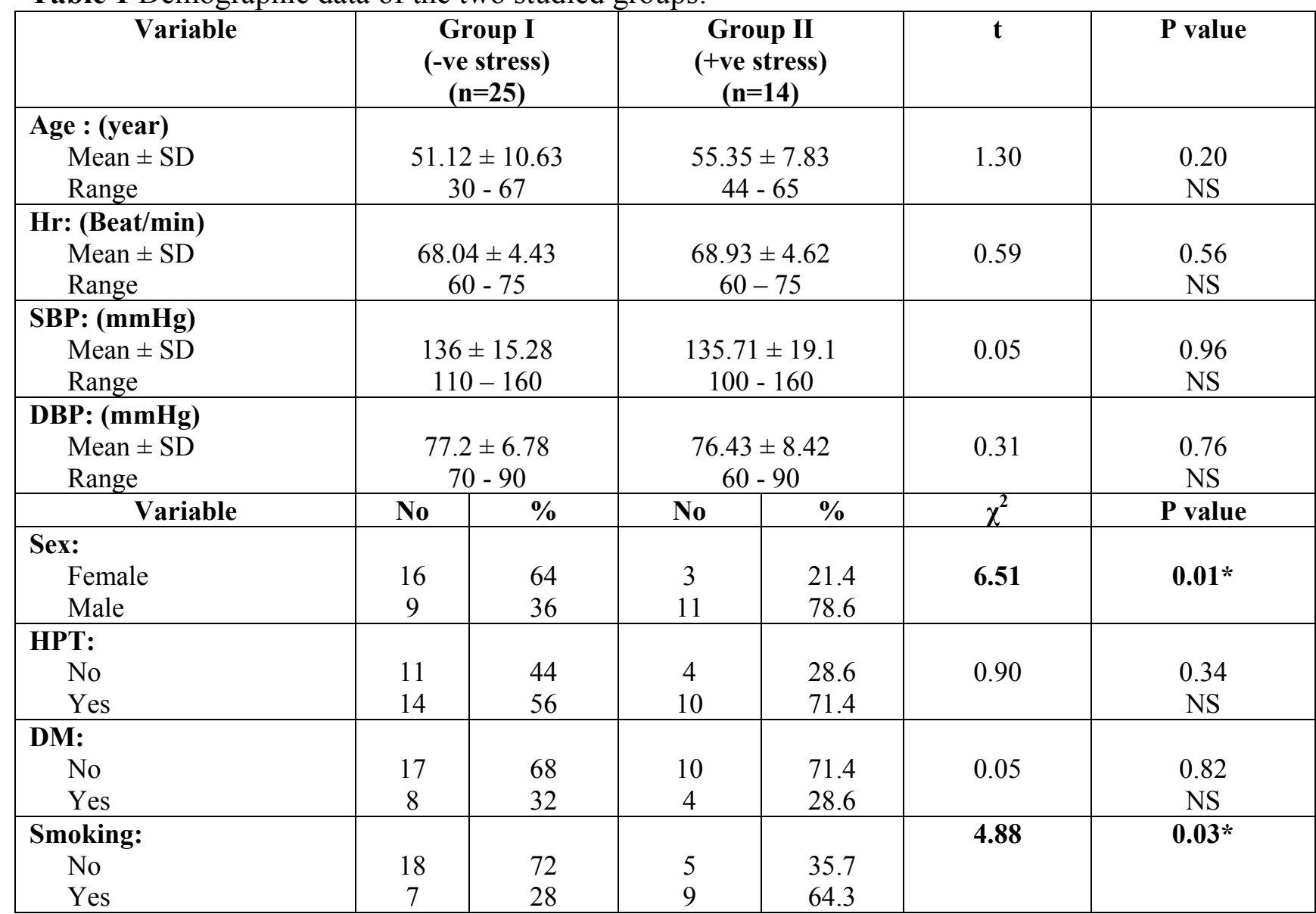

SD: standard deviation $\quad \mathrm{t}$ : Independent $\mathrm{t}$ test $\quad \chi 2$ :Chi square test NS:Non significant $(\mathrm{P}>0.05)$

*: Significant $(\mathrm{P}<0.05)$ 
Table 2 Lab results among the two studied groups

\begin{tabular}{|c|c|c|c|c|}
\hline Variable & $\begin{array}{c}\text { Group I } \\
(- \text { ve stress) } \\
(n=25)\end{array}$ & $\begin{array}{c}\text { Group II } \\
(+ \text { ve stress }) \\
(\mathbf{n}=14)\end{array}$ & $t$ & $P$ value \\
\hline $\begin{array}{c}\text { Cholesterol: }(\mathbf{m g} / \mathbf{d l}) \\
\text { Mean } \pm S D \\
\text { Range }\end{array}$ & $\begin{array}{c}180.08 \pm 52.75 \\
112-290\end{array}$ & $\begin{array}{c}207.21 \pm 69.47 \\
128-381\end{array}$ & 1.38 & $\begin{array}{c}0.18 \\
\mathrm{NS}\end{array}$ \\
\hline $\begin{array}{l}\text { TG: }(\mathbf{m g} / \mathbf{d l}) \\
\quad \text { Mean } \pm S D \\
\quad \text { Range }\end{array}$ & $\begin{array}{c}130.80 \pm 48.11 \\
53-248\end{array}$ & $\begin{array}{c}136.57 \pm 40.24 \\
78-202\end{array}$ & 0.38 & $\begin{array}{l}0.71 \\
\mathrm{NS}\end{array}$ \\
\hline $\begin{array}{c}\text { LDL: }(\mathbf{m g} / \mathbf{d l}) \\
\text { Mean } \pm S D \\
\text { Range }\end{array}$ & $\begin{array}{c}134.88 \pm 29.29 \\
86-186\end{array}$ & $\begin{array}{c}152.29 \pm 31.39 \\
110-220\end{array}$ & 1.74 & $\begin{array}{c}0.09 \\
\text { NS }\end{array}$ \\
\hline $\begin{array}{c}\text { HDL: }(\mathbf{m g} / \mathbf{d l}) \\
\text { Mean } \pm S D \\
\text { Range }\end{array}$ & $\begin{array}{c}46.32 \pm 7.03 \\
33-58\end{array}$ & $\begin{array}{c}45.5 \pm 6.79 \\
33-55\end{array}$ & 0.35 & $\begin{array}{c}0.73 \\
\mathrm{NS}\end{array}$ \\
\hline $\begin{array}{c}\text { Creatinine: }(\mathbf{m g} / \mathbf{d l}) \\
\text { Mean } \pm S D \\
\text { Range }\end{array}$ & $\begin{array}{c}0.96 \pm 0.24 \\
0.6-1.3 \\
\end{array}$ & $\begin{array}{c}0.94 \pm 0.25 \\
0.7-1.6\end{array}$ & 0.23 & $\begin{array}{c}0.82 \\
\mathrm{NS}\end{array}$ \\
\hline $\begin{array}{c}\text { FBS: }(\mathbf{m g} / \mathbf{d l}) \\
\text { Mean } \pm S D \\
\text { Median } \\
\text { Range }\end{array}$ & $\begin{array}{c}110.32 \pm 44.67 \\
89 \\
71-215\end{array}$ & $\begin{array}{c}105.64 \pm 30.13 \\
95.5 \\
70-175\end{array}$ & $\begin{array}{c}\text { MW } \\
0.0 .38\end{array}$ & $\begin{array}{c}0.70 \\
\text { NS }\end{array}$ \\
\hline $\begin{array}{c}\text { MCP-1: }(\mathbf{p g} / \mathbf{m l}) \\
\text { Mean } \pm S D \\
\text { Median } \\
\text { Range }\end{array}$ & $\begin{array}{c}183.24 \pm 136.03 \\
117 \\
53-480\end{array}$ & $\begin{array}{c}333 \pm 152.41 \\
368.5 \\
73-568\end{array}$ & $\begin{array}{l}\text { MW } \\
2.75\end{array}$ & 0.006 *** \\
\hline
\end{tabular}

TG: Triglyceride LDL: low density of lipoprotein HDL: high density of lipoprotein FBS: Fasting blood sugar MCP-1: Monocyte Chemoattractant Protein-1 Sd: Standard deviation $\quad t$ : Independent t test MW: Mann Whitney test NS: Non significant $(\mathrm{P}>0.05) \quad$ **: Highly significant $(\mathrm{P}<0.01)$

Table 3 Angiography results among the two studied groups

\begin{tabular}{|c|c|c|c|c|}
\hline Variable & $\begin{array}{c}\text { Group I } \\
(-\mathbf{v e} \text { stress }) \\
(\mathbf{n}=\mathbf{2 5})\end{array}$ & $\begin{array}{l}\text { Group II } \\
(+ \text { ve stress }) \\
(n=14)\end{array}$ & $\chi^{2}$ & $\mathbf{P}$ \\
\hline $\begin{array}{l}\text { LM: } \\
\text { Normal } \\
\text { Medium artery }\end{array}$ & $\begin{array}{c}22(88 \%) \\
3(12 \%)\end{array}$ & $\begin{array}{l}14(100 \%) \\
0(0.00 \%)\end{array}$ & 1.82 & $\begin{array}{l}0.18 \\
\text { NS }\end{array}$ \\
\hline $\begin{array}{l}\text { LAD: } \\
\text { Normal } \\
\text { No significant lesion } \\
\text { Atherosclerotic vessel with stenotic lesion }\end{array}$ & $\begin{array}{c}13(52 \%) \\
1(4 \%) \\
11(44 \%)\end{array}$ & $\begin{array}{c}4(28.6 \%) \\
3(21.4 \%) \\
7(50 \%)\end{array}$ & 3.86 & $\begin{array}{c}0.15 \\
\text { NS }\end{array}$ \\
\hline $\begin{array}{l}\text { LCX: } \\
\text { Normal } \\
\text { No significant lesion } \\
\text { Atherosclerotic vessel with stenotic lesion }\end{array}$ & $\begin{array}{l}19(76 \%) \\
3(12 \%) \\
3(12 \%)\end{array}$ & $\begin{array}{l}8(57.1 \%) \\
3(21.4 \%) \\
3(21.4 \%)\end{array}$ & 1.50 & $\begin{array}{c}0.47 \\
\text { NS }\end{array}$ \\
\hline $\begin{array}{l}\text { RCA: } \\
\text { Normal } \\
\text { No significant lesion } \\
\text { Atherosclerotic vessel with stenotic lesion }\end{array}$ & $\begin{array}{l}19(76 \%) \\
3(12 \%) \\
3(12 \%)\end{array}$ & $\begin{array}{l}9(64.3 \%) \\
1(7.1 \%) \\
4(28.6 \%)\end{array}$ & 1.75 & $\begin{array}{c}0.42 \\
\text { NS }\end{array}$ \\
\hline $\begin{array}{l}\text { No. of vessels: } \\
\text { No } \\
1\end{array}$ & $\begin{array}{c}14(56 \%) \\
6(24 \%)\end{array}$ & $\begin{array}{l}6(42.9 \%) \\
4(28.6 \%)\end{array}$ & 0.70 & $\begin{array}{l}0.87 \\
\text { NS }\end{array}$ \\
\hline
\end{tabular}




\begin{tabular}{|l|c|c|c|c|}
\hline $\mathbf{2}$ & $4(16 \%)$ & $3(21.4 \%)$ & & \\
$\mathbf{3}$ & $1(4 \%)$ & $1(7.1 \%)$ & & \\
\hline No. of lesions: & $14(56 \%)$ & $6(42.9 \%)$ & & NS \\
No & $6(24 \%)$ & $0(0.00 \%)$ & & \\
$\mathbf{1}$ & $2(8 \%)$ & $5(35.7 \%)$ & & \\
$\mathbf{2}$ & $1(4 \%)$ & $1(7.1 \%)$ & & \\
$\mathbf{3}$ & $2(8 \%)$ & $2(14.3 \%)$ & & \\
$\mathbf{4}$ & $6.88 \pm 10.13$ & $8.25 \pm 10.13$ & 0.71 & NS \\
\hline Syntax: & $5(0-31.5)$ & $6(0-34)$ & & \\
Mean \pm SD & & & \\
Median (Range) & & & \\
\hline
\end{tabular}

LM: left main disease LAD: Left anterior descending coronary artery

LCX: left circumference coronary artery RCA: Right coronary artery Sd: Standard deviation MW: Mann Whitney test $\quad \chi^{2}$ :Chi square test $\quad$ NS:Non Significant $(\mathrm{P}>0.05)$

Table 4 Correlation between MCP-1 and laboratory findings syntax-score and number of lesions and vessels among the studied cases

\begin{tabular}{|l|c|c|}
\hline \multicolumn{1}{|c|}{ Variable } & \multicolumn{2}{c|}{$\begin{array}{c}\text { MCP-1 } \\
(\boldsymbol{n}=\mathbf{3 9})\end{array}$} \\
\cline { 2 - 3 } & \multicolumn{2}{c|}{$\boldsymbol{P}$} \\
\hline Syntax & $\mathbf{0 . 7 3}$ & $<\mathbf{0 . 0 0 1 * *}$ \\
\hline Cholesterol (mg/dl) & 0.29 & $0.07 \mathrm{NS}$ \\
\hline TG (mg/dl) & 0.16 & $0.33 \mathrm{NS}$ \\
\hline LDL (mg/dl) & $\mathbf{0 . 4 1}$ & $\mathbf{0 . 0 0 9 * *}$ \\
\hline HDL (mg/dl) & -0.24 & $0.14 \mathrm{NS}$ \\
\hline Creatinine (mg/dl) & -0.05 & $0.75 \mathrm{NS}$ \\
\hline FBS (mg/dl) & 0.12 & $0.48 \mathrm{NS}$ \\
\hline No of lesions & $\mathbf{0 . 7 3}$ & $<\mathbf{0 . 0 0 1 * *}$ \\
\hline No of vessels & $\mathbf{0 . 7 4}$ & $<\mathbf{0 . 0 0 1 * *}$ \\
\hline
\end{tabular}

TG: Triglyceride LDL: low density of lipoprotein HDL: high density of lipoprotein

FBS: Fasting blood sugar $\quad$ MCP-1: Monocyte Chemoattractant Protein-1

NS: Non significant $(\mathrm{P}>0.05) \quad * *$ : Highly significant $(\mathrm{P}<0.01)$

$\boldsymbol{r}$ : Spearman correlation coefficient

Table 5 Correlation between Syntax and laboratory findings and number of lesions and vessels among the studied cases

\begin{tabular}{|l|c|c|}
\hline \multirow{2}{*}{ Variable } & \multicolumn{2}{c|}{$\begin{array}{c}\text { Syntax } \\
(\mathbf{n = 3 9 )}\end{array}$} \\
\cline { 2 - 3 } & \multicolumn{2}{c|}{$\boldsymbol{P}$} \\
\hline Cholesterol (mg/dl) & 0.27 & $0.10 \mathrm{NS}$ \\
\hline TG (mg/dl) & 0.11 & $0.52 \mathrm{NS}$ \\
\hline LDL (mg/dl) & $\mathbf{0 . 4 4}$ & $\mathbf{0 . 0 0 5 * *}$ \\
\hline HDL (mg/dl) & -0.13 & $0.44 \mathrm{NS}$ \\
\hline Creatinine (mg/dl) & 0.11 & $0.52 \mathrm{NS}$ \\
\hline FBS (mg/dl) & 0.002 & $0.99 \mathrm{NS}$ \\
\hline No of lesions & $\mathbf{0 . 9 6}$ & $<\mathbf{0 . 0 0 1 * *}$ \\
\hline No of vessels & $\mathbf{0 . 9 7}$ & $<\mathbf{0 . 0 0 1 * *}$ \\
\hline
\end{tabular}

TG: Triglyceride LDL: low density of lipoprotein $\quad$ HDL: high density of lipoprotein

FBS: Fasting blood sugar NS: Non significant $(\mathrm{P}>0.05) \quad * *$ : Highly significant $(\mathrm{P}<0.01)$ $\boldsymbol{r}$ : Spearman correlation coefficient

March 2019 Volume 25 Issue $2 \quad$ www.zumj.journals.ekb.eg 
Adel et al... Zagazig University Medical Journals

Table 6 Relation between Co-morbidity and smoking among the two studied groups and MCP-1

\begin{tabular}{|c|c|c|c|c|c|c|c|c|}
\hline \multirow[t]{2}{*}{ Groups } & \multirow[t]{2}{*}{ Variable } & \multicolumn{5}{|c|}{ МCP-1 } & \multirow[t]{2}{*}{ MW } & \multirow[t]{2}{*}{$\mathbf{P}$} \\
\hline & & $\mathbf{N}$ & Mean & SD & Median & Range & & \\
\hline \multirow{3}{*}{ Group I } & $\begin{array}{c}\text { HPT: } \\
N o \\
Y e s\end{array}$ & $\begin{array}{l}11 \\
14\end{array}$ & $\begin{array}{l}133.55 \\
222.29\end{array}$ & $\begin{array}{l}132.94 \\
129.74\end{array}$ & $\begin{array}{c}79 \\
226\end{array}$ & $\begin{array}{l}53-480 \\
63-444\end{array}$ & 2.36 & $0.02 \%$ \\
\hline & $\begin{array}{c}\text { DM: } \\
\text { No } \\
Y e s \\
\end{array}$ & $\begin{array}{c}17 \\
8 \\
\end{array}$ & $\begin{array}{c}155 \\
243.25 \\
\end{array}$ & $\begin{array}{l}121.53 \\
153.72 \\
\end{array}$ & $\begin{array}{c}91 \\
213.5 \\
\end{array}$ & $\begin{array}{l}53-444 \\
79-480 \\
\end{array}$ & 2.18 & $0.04 \%$ \\
\hline & $\begin{array}{c}\text { Smoking: } \\
\text { No } \\
Y e s \\
\end{array}$ & $\begin{array}{c}18 \\
7 \\
\end{array}$ & $\begin{array}{l}144.22 \\
283.57\end{array}$ & $\begin{array}{l}123.34 \\
120.82 \\
\end{array}$ & $\begin{array}{c}93 \\
287 \\
\end{array}$ & $\begin{array}{l}53-480 \\
88-444 \\
\end{array}$ & 2.42 & $0.02 *$ \\
\hline \multirow{3}{*}{ Group II } & $\begin{array}{c}\text { HPT: } \\
\text { No } \\
\text { Yes }\end{array}$ & $\begin{array}{c}4 \\
10\end{array}$ & $\begin{array}{c}276 \\
355.8\end{array}$ & $\begin{array}{l}167.55 \\
148.91\end{array}$ & $\begin{array}{c}280.5 \\
394\end{array}$ & $\begin{array}{l}86-457 \\
73-568\end{array}$ & 0.99 & $\begin{array}{l}0.32 \\
\mathrm{NS}\end{array}$ \\
\hline & $\begin{array}{c}\text { DM: } \\
\text { No } \\
\text { Yes } \\
\end{array}$ & $\begin{array}{c}10 \\
4 \\
\end{array}$ & $\begin{array}{c}318 \\
370.5 \\
\end{array}$ & $\begin{array}{l}165.45 \\
126.14 \\
\end{array}$ & $\begin{array}{l}329 \\
412 \\
\end{array}$ & $\begin{array}{c}73-568 \\
193-464 \\
\end{array}$ & 0.42 & $\begin{array}{c}0.76 \\
\mathrm{NS}\end{array}$ \\
\hline & $\begin{array}{c}\text { Smoking: } \\
\text { No } \\
Y e s\end{array}$ & $\begin{array}{l}5 \\
9\end{array}$ & $\begin{array}{l}303 \\
387\end{array}$ & $\begin{array}{l}115.31 \\
168.12\end{array}$ & $\begin{array}{l}353 \\
389\end{array}$ & $\begin{array}{c}73-464 \\
193-586\end{array}$ & 0.73 & $\begin{array}{c}0.64 \\
\text { NS }\end{array}$ \\
\hline
\end{tabular}

Sd: Standard deviation

MW: Mann Whitney test NS:Non significant $(\mathrm{P}>0.05)$

$*$ :Significant $(\mathrm{P}<0.05)$

Table 7 Relation between angiography among the two studied groups and MCP-1:

\begin{tabular}{|c|c|c|c|c|c|c|c|c|}
\hline \multirow[t]{2}{*}{ Groups } & \multirow[t]{2}{*}{ Variable } & \multicolumn{5}{|c|}{ МСР-1 } & \multirow[t]{2}{*}{ Test } & \multirow[t]{2}{*}{$P$ value } \\
\hline & & $\mathbf{N}$ & Mean & SD & Median & Range & & \\
\hline \multirow{4}{*}{ Group I } & $\begin{array}{l}\text { LM: } \\
\text { Normal } \\
\text { Abnormal } \\
\end{array}$ & $\begin{array}{c}22 \\
3 \\
\end{array}$ & $\begin{array}{c}164.5 \\
320.67\end{array}$ & $\begin{array}{l}126.33 \\
149.28 \\
\end{array}$ & $\begin{array}{c}102.5 \\
271 \\
\end{array}$ & $\begin{array}{c}53-480 \\
149-420 \\
\end{array}$ & $\begin{array}{l}\text { MW } \\
2.17\end{array}$ & $\begin{array}{c}0.04 * \\
\text { S }\end{array}$ \\
\hline & $\begin{array}{l}\text { LAD: } \\
\text { Normal } \\
\text { No significant } \\
\text { significant lesion }\end{array}$ & $\begin{array}{c}13 \\
1 \\
11 \\
\end{array}$ & $\begin{array}{c}79.85 \\
149 \\
308.55\end{array}$ & $\begin{array}{c}19.86 \\
0 \\
112.47 \\
\end{array}$ & $\begin{array}{c}79 \\
149 \\
287 \\
\end{array}$ & $\begin{array}{c}53-117 \\
149 \\
140-480 \\
\end{array}$ & $\begin{array}{c}K \\
18.42\end{array}$ & $<0.001 * *$ \\
\hline & $\begin{array}{l}\text { LCX: } \\
\text { Normal } \\
\text { No significant } \\
\text { significant lesion }\end{array}$ & $\begin{array}{c}19 \\
3 \\
3 \\
\end{array}$ & $\begin{array}{l}152.05 \\
259.67 \\
304.33\end{array}$ & $\begin{array}{l}130.09 \\
123.57 \\
120.23 \\
\end{array}$ & $\begin{array}{c}91 \\
237 \\
313 \\
\end{array}$ & $\begin{array}{c}53-480 \\
149-393 \\
180-420 \\
\end{array}$ & $\begin{array}{c}\mathrm{K} \\
5.62\end{array}$ & $\begin{array}{c}0.04 * \\
\text { S }\end{array}$ \\
\hline & $\begin{array}{l}\text { RCA: } \\
\text { Normal } \\
\text { No significant } \\
\text { significant lesion }\end{array}$ & $\begin{array}{c}19 \\
3 \\
3 \\
\end{array}$ & $\begin{array}{c}134.63 \\
375.33 \\
299\end{array}$ & $\begin{array}{c}103.10 \\
55.64 \\
159.32 \\
\end{array}$ & $\begin{array}{c}91 \\
393 \\
237 \\
\end{array}$ & $\begin{array}{c}53-444 \\
313-420 \\
180-480 \\
\end{array}$ & $\begin{array}{c}\text { K } \\
9.09\end{array}$ & $\begin{array}{c}0.01 * \\
\mathrm{~S}\end{array}$ \\
\hline \multirow{4}{*}{ Group II } & $\begin{array}{l}\text { LM: } \\
\text { Normal } \\
\text { Abnormal }\end{array}$ & $\begin{array}{c}14 \\
0 \\
\end{array}$ & $\begin{array}{c}333 \\
--- \\
\end{array}$ & $\begin{array}{c}152.41 \\
---\end{array}$ & $\begin{array}{c}368.5 \\
---\end{array}$ & $\begin{array}{c}73-568 \\
----\end{array}$ & -- & -- \\
\hline & $\begin{array}{l}\text { LAD: } \\
\text { Normal } \\
\text { No significant } \\
\text { significant lesion }\end{array}$ & $\begin{array}{l}4 \\
3 \\
7\end{array}$ & $\begin{array}{l}147.75 \\
350.33 \\
431.43 \\
\end{array}$ & $\begin{array}{c}81.19 \\
124.06 \\
87.02 \\
\end{array}$ & $\begin{array}{l}215 \\
369 \\
453 \\
\end{array}$ & $\begin{array}{c}73-293 \\
218-464 \\
289-568 \\
\end{array}$ & $\begin{array}{c}\mathbf{K} \\
7.7\end{array}$ & $\begin{array}{c}0.02 * \\
\mathrm{~S}\end{array}$ \\
\hline & $\begin{array}{l}\text { LCX: } \\
\text { Normal } \\
\text { No significant } \\
\text { significant lesion }\end{array}$ & $\begin{array}{l}8 \\
3 \\
3 \\
\end{array}$ & $\begin{array}{c}315.25 \\
275.33 \\
438\end{array}$ & $\begin{array}{c}170.53 \\
81.79 \\
140.47 \\
\end{array}$ & $\begin{array}{l}310 \\
293 \\
457 \\
\end{array}$ & $\begin{array}{r}73-466 \\
218-369 \\
289-568 \\
\end{array}$ & $\begin{array}{c}K \\
6.92\end{array}$ & $\begin{array}{c}\text { 0.03* } \\
\text { S }\end{array}$ \\
\hline & $\begin{array}{l}\text { RCA: } \\
\text { Normal } \\
\text { No significant } \\
\text { signifcant lesion }\end{array}$ & $\begin{array}{l}9 \\
1 \\
4\end{array}$ & $\begin{array}{l}261 \\
457 \\
464 \\
\end{array}$ & $\begin{array}{c}137.54 \\
0 \\
81.58\end{array}$ & $\begin{array}{l}239 \\
457 \\
459\end{array}$ & $\begin{array}{c}73-464 \\
475 \\
369-568 \\
\end{array}$ & $\begin{array}{c}K \\
6.09\end{array}$ & $\begin{array}{c}0.04 * \\
\mathrm{~S}\end{array}$ \\
\hline
\end{tabular}

K: Kruskal Wallis test MW: Mann Whitney test $\quad$ *: Significant $(\mathrm{P}<0.05) \quad$ **: Highly significant $(\mathrm{P}<0.01)$ 


\section{DISCUSSION}

All patients in the present study were divided into two groups; Group I: include 25 patients with negative exercise test; they were $9(36 \%)$ males and $16(64 \%)$ females with the mean age was $\mathbf{5 1 . 1 2} \pm \mathbf{1 0 . 6 3}$ (ranging 30-67) years. Group II: include 14 patients with positive exercise test; they were $11(78.6 \%)$ males and $3(21.4 \%)$ females with the mean age were $\mathbf{5 5 . 3 5} \pm \mathbf{7 . 8 3}$ (ranging 44-65) years were investigated.

In clinical practice coronary stenosis is often considered as the main cause of myocardial ischemia. However, other causes should be considered especially in normal coronary angoigraphy in documented cases of ischemic heart disease (IHD). Although there are many advances in modalities for evaluation of coronary lesions, however the coronary angiography remains the "gold standard" for identifying the presence or absence of stenosis in coronary arteries and meanwhile provides reliable information during percutaneous coronary intervention. There was no statistical significant difference between Group I (-ve stress) and Group II (+ve stress) in invasive angiographic findings $(\mathrm{p}>0.05)$. In contrast to our findings, Nguyen et al. ${ }^{[24]}$ found that $60 \%$ of evaluated patient were presenting with normal angiography. Previously, Manfroi and coworkers found the acute myocardial infarction was the first manifestation of IHD in $49 \%$ of the patients. The associated risk factors were systemic arterial hypertension and left ventricular hypertrophy. The remaining risk factors were not statistically significant.On the other hand, the study of Mohammad and colleagues found a significant association between the risk factors and the angiographic characteristics in patients with IHD. There were more significantly stenosed lesions among patients with $>3$ risk factors compared to patients with $<3$ risk factors $(p<0.05)$. Lesions were more diffused $(\mathrm{p}<0.01)$, with higher incidence of left ventricular dysfunction $(p<$ 0.001) among former patients compared to later ones. They concluded that, significant findings were observed in the angiographic profile of patients with multiple risk factors. There were more multi-vessels and diffused angiographic findings among patients with chronic stable angina ${ }^{[25]}$.

The SYNTAX score is an angiographic grading tool to determine the functional complexity of CAD. The SYNTAX score was developed as a tool to assess the complexity of coronary lesions in the SYNTAX (Synergy between Percutaneous Coronary Intervention with TAXUS and Cardiac Surgery) study. Later, this score was seen also to correlate with clinical outcomes.

In a study of Martín-Reyes et al., they demonstrate, for the first time, that high MCP-1 levels predict independently the existence of a high SS. This is a chemokine that plays a key role in the recruitment of monocytes into the vascular wall during atherogenesis. In accordance with this, MCP1 plasma levels predict the risk of cardiovascular events in patients with stable $\mathrm{CAD}$ and acute coronary syndrome. Therefore, the ability of MCP-1 to predict the complexity of CAD fits with its known properties. Therefore, Increased MCP-1 plasma levels are independently associated with high Syntax score. In the present study we compared parameters like Syntax score, lipid profile, creatinine, duration of DM, smoking, and number of lesions and vessels among the studied cases with IHD. In this study the Syntax-score was used for description of coronary artery impairment enabling statistical processing. Our finding shows that circulating MCP-1 levels correlate with CAD and with Syntax-score. Statistically, there were positive significant correlation between MCP-1 and syntax-score of lesions and number of vessels and LDL. Also, we found positive significant correlation between syntax-score and number of vessels, number of lesions and LDL in the studied cases. it is goes with Nozwa et al., ${ }^{[27]}$. Their results suggest that circulating monocytes play an important role in the progression of coronary plaque in IHD and that the peak monocyte count during hospitalization might be a predictor of plaque progression.

Griva et al., reported that according to the Spearman correlation coefficient there was significant association between MCP-1 level and Syntax-score $(0.358, \mathrm{a}=0.05)$. These data 


\section{Adel et al...}

suggest association between the extent of CAD and circulating MCP-1. They failed to demonstrate any association with the other investigated biomarkers.

According to our findings the concentrations of circulating MCP-1 and LDL levels significantly differ between the studied groups. In contrast of our findings were differed with the study of Griva et al. ${ }^{[17]}$ who fond no significant interdependence of circulating MCP-1 levels and Syntax-score. MCP-1 levels were significantly different in patients with CAD.

Assuming that the Syntax-score has the ability to describe anatomical and functional features of CAD, we suggest that MCP-1 levels can predict the extent of coronary artery impairment. Even though a promising biomarker of atherosclerosis, Griva et al. ${ }^{[17]}$ have not succeeded in confirming an association between circulating MCP-1 levels and Syntax-score.

The current study shows no statistical significance relation between DM, HPT and smoking and MPC-1 in Group II (+ve stress); but there were statistical significance increase in mean MCP-1 level among hypertensive, diabetic and smoking cases in Group I (-ve stress). The present study a significantly increase in MCP-1 level among significant lesions cases in all parameters in both Groups. In the relation between angiography findings and Syntax-score among the studied groups, the present study show a statistical significance increasing in syntax-score among significant lesions cases in all parameters in both Group I and Group II ${ }^{[28]}$.

Syntax score takes in consideration the severity of CAD not only with respect to location of lesion, number of vessels involved, number and location of lesions, type of occlusion, presence of stenosis, tortuosity, and involvement of thrombus or calcification, but also duration of occlusion. Hence Syntax score gives a complete insight about the CAD lesion with respect to severity and intensity of disease. More the Syntax score more severe is the CAD. It is well known that DM worsens the CAD and affects outcome not only by increasing the severity but also by the association of micro- and macrovascular complications $^{[29]}$.

\section{Zagazig University Medical Journals}

This study shows the sensitivity of MCP-1 at cut off 186.5 was $71.4 \%$, specificity was $72 \%$ and the accuracy was $71.8 \%$. Also, our findings shows that the sensitivity of MCP-1 at cut off 113.5 in diagnosis of abnormal angiography among -ve stress cases was $91.7 \%$, specificity was $84.6 \%$ and the accuracy was $88 \%^{[32-36]}$.

The present study show a significant predictor for syntax among the studied group was MCP-1, number of vessels, number of lesions and angiography findings. Similarly, Sahinarslan et al. found in multivariate analysis, only serum MCP-1 level was independently related to good coronary collateral development. Higher serum MCP-1 level is related to better coronary collateral development ${ }^{[37,38]}$.

\section{CONCLUSION}

Our Study concluded that MCP-1 at cut off value $113.5 \mathrm{ng} / \mathrm{l}$ can predict the presence of significant coronary artery lesion need intervention in patient with chest pain and negative exercise test. Also $\mathrm{We}$ found that MCP-1 at cut off value $406 \mathrm{ng} / 1$ is correlated to heigh syntax score,that guide the decision for CABG against PCI .

The study recommended the assessment of MCP-1 in serum of CAD patients with chronic stable angina. However, MCP-1 was increase propability of IHD diagnosis in negative stress excercies.

MCP-1 provides a useful marker of severity of coronary atherosclerosis in IHD apart from other risk factors and can be used for risk straifaction in IHD

Further studies with large sample size are required to clarift the significance of MCP-1 in IHD patients Assessment of MCP-1level after medical and/or interventional treatment of IHD patients as indicator of prognosis in IHD patients either acute or chronic

Conflict of Interest: Non declared. Funding: No funding sources.

\section{REFERENCES}

1. Abdallah MS, Wang K, Magnuson EA, et al (2017): Quality of Life After Surgery or DES in Patients With 3-Vessel or Left Main Disease. J Am Coll Cardiol; 69:2039- 2050

2. Woodruffe S, Neubeck L, Clark R, et al 


\section{Adel et al...}

(2014): Australian Cardiovascular Health and Rehabilitation Association (ACRA) core components of cardiovascular disease secondary prevention and cardiac rehabilitation. Heart Lung Circ; 24:430-441.

3. Xu R, Li C, Qian J, et al (2015): Computed tomography-derived fractional flow reserve in the detection of lesion-specific ischemia: an integrated analysis of 3 pivotal trials. Medicine (Baltimore); 94:e1963

4. Yadav M, Palmerini T, Caixeta A, et al (2013): Prediction of coronary risk by SYNTAX and derived scores: synergy between percutaneous coronary intervention with taxus and cardiac surgery,JAm Coll Cardiol. 2013 Oct 1;62(14):1219-1230. doi: 10.1016/j.jacc.2013.06.047. Epub 2013 Aug 7

5. Akbarzadeh F, Pourafkari L, HashemiJazi SM, et al (2010): Prevalence and severity of coronary of artery disease among hypertensive and normotensive patients. ARYA Atherosclerosis Journal; 5: 186-190.

6. Anderson L, Oldridge N, Thompson DR, et al (2016): Exercise-based cardiac rehabilitation for coronary heart disease: cochrane systematic review and meta-analysis. J Am Coll Cardiol; 67:1-12.

7. Berg KE, Ljungcrantz I, Andersson L, et al (2012): Elevated CD14+ +CD16 monocytes predict cardiovascular events. Circ. Cardiovasc. Genet; 5: 122-131

8. Boden WE, Franklin B, Berra K, et al (2014): Exercise as a therapeutic intervention in patients with stable ischemic heart disease: an underfilled prescription. The American Journal of Medicine; 127 (10): 905-11.

9. Yokochi S, Hashimoto H, Ishiwata $\mathrm{Y}$, et al (2001): An anti-inflammatory drug, propagermanium, may target GPI-anchored proteins associated with na MCP-1 receptor, CCR2. J Interferon Cytokine Res; 21: 389398

10.Franklin BA, Whaley MH, Howley ET, et al (2000): American College of Sports Medicine. ACSM's guidelines for exercise testing and prescription. 6th ed. Baltimore, MD: Lippincott Williams \& Wilkins; 2000.

11.D'Alessandra Y, Carena MC, Spazzafumo L, et al (2013): Diagnostic potential of plasmatic MicroRNA signatures in stable and unstable angina. PLoS One; 8:e80345.

12.de Lemos JA, Morrow DA, Sabatine MS, et al (2003): Association between plasma levels of monocyte chemoattractant protein-1 and longterm clinical outcomes in patients with acute coronary syndromes. Circulation; 107(5):690-5.

March 2019 Volume 25 Issue 2

\section{Zagazig University Medical Journals}

13.Douglas P, Patel M, Bailey S, et al. (2011) Hospital variability in the rate of finding obstructive coronary artery disease atelective, diagnostic coronary angiography. J Am Coll Cardiol.; 58:801-9.

14.Gautier EL, Jakubzick C, and Randolph GJ (2009): Regulation of the migration and survival of monocyte subsets by chemokine receptors and its relevance to atherosclerosis. Arterioscler Thromb Vasc Biol; 29: 1412- 18

15.Go AS, Mozaffarian D, Roger VL, et al (2014): Heart disease and stroke statistics-2014 update: a report from the American Heart Association. Circulation; 129:e28-e292.

16.Gus I, Fischmann A, and Medina C (2002): Prevalence of risk factors for coronary artery disease in the brazilian state of rio grande do sul, Arquivos Brasileiros de Cardiologia; 78: 484-90.

17.Kazemi-Bajestani SM, Ghayour-Mobarhan M, Ebrahimi M, et al (2007): Serum copper and zinc concentrations are lower in Iranian patients with angiographically defined coronary artery disease than in subjects with a normal angiogram. Journal of Trace Elements in Medicine and Biology; 21: 22-28.

18.Kempf T, Sinning JM, Quint A, et al (2009): Growth-differentiation factor-15 for risk stratification in patients with stable and unstable coronary heart disease: results from the AtheroGene study.Circ Cardiovasc Genet; 2:286-92.

19.Li H, Cybulsky MI, Gimbrone MA, et al (1993): an athero genic diet rapidly induces VCAM-1, cytokine regulatable mononuclear leukocyte adhesion molecule, in rabbit aortic endothelium. Arterioscler Thromb; 13(2):197204

20.Mohammad AM, Sheikho SK, and Tayib JM (2013): Relation of Cardiovascular Risk Factors with Coronary Angiographic Findings in Iraqi Patients with Ischemic Heart Disease. American Journal of Cardiovascular Disease Research; 1, (1): 25-29.

21.Nishikura T, Koba S, Yokota Y, et al (2014): Elevated small dense low- density lipoprotein cholesterol as a predictor for future cardiovascular events in patients with stable coronary artery disease. J Atheroscler Thromb; 21:755-67.

22.Ockene IS, and Miller NH (1997): Cigarette smoking, cardiovascular disease, and stroke. A statement for healthcare professionals from the American Heart Association. Circulation; 96: 3243-3247.

23.Okamoto M, Fuchigami M, Suzuki $T$, et al (2012): A novel C-C chemokine receptor 2 


\section{Adel et al...}

antagonist prevents progression of albuminuria and atherosclerosis in mouse models. Biol Pharm Bull; 35: 2069-2074

24.Omland T, Pfeffer MA, Solomon SD, et al (2013): Prognostic value of cardiac troponin I measured with a highly sensitive assay in patients with stable coronary artery disease. J Am Coll Cardiol; 61:1240-9.

25.Parizadeh SM, Moohebati M, Ghafoori F, et al (2009): Serum selenium and glutathione peroxidase concentrations in Iranian patients with angiography-defined coronary artery disease. Angiology; 60: 186-191.

26.Pencina MJ, D'Agostino RB Sr., Steyerberg EW (2011): Extensions of net reclassification improvement calculations to measure usefulness of new biomarkers. Stat Med; $30: 11-21$.

27.Rosjo H, Kravdal G, Hoiseth AD, et al (2012): Troponin I measured by a highsensitivity assay in patients with suspected reversible myocardial ischemia: data from the Akershus Cardiac Examination (ACE) 1 study. Clin Chem; 58:1565-73.

28. Schulte C, Molz S, Appelbaum S, et al (2015): miRNA-197 and miRNA-223 predict cardiovascular death in a cohort of patients with symptomatic coronary artery disease. PLoS One; 10:e0145930.

29. Solomon SD, Rice MM, K AJ, et al (2006): Renal function and effectiveness of angiotensin-converting enzyme inhibitor therapy in patients with chronic stable coronary disease in the Prevention of Events with ACE inhibition (PEACE) trial. Circulation; 114:26-31.

30. Szalai C, Duba J, Prohaszka Z, et al (2001): Involvement of polymorphisms in the chemokine system in the susceptibility for

\section{Zagazig University Medical Journals}

coronary artery disease (CAD). Coincidence of elevated Lp(a) and MCP-1 $-2518 \mathrm{G} / \mathrm{G}$ genotype in $\mathrm{CAD}$ patients. Atherosclerosis; 158:233-239.

31.Tang WH, Wu Y, Nicholls SJ, et al (2011): Plasma myelo-peroxidase predicts incident cardiovascular risks in stable patients undergoing medical management for coronary artery disease. Clin Chem; 57:33-9.

32.Tsujioka $H$, Imanishi $T$, Ikejima $H$, et al (2009): Impact of heterogeneity of human peripheral blood monocyte subsets on myocardial salvage in patients with primary acute myocardial infarction. J Am Coll Cardiol; 54: 130-138

33.WHO MONICA (1988): Project Principal Investigators. The World Health Organization MONICA Project (monitoring trends and determinants in cardiovascular disease): a major international collaboration. J Clin Epidemiol; 41:105-14.

34.Ziegler-Heitbrock L, Ancuta P, Crowe S, et al (2010): Nomenclature of monocytes and dendritic cells in blood. Blood; 116: e74-e80

35.Bruder O, Wagner A, and Lombardi $M$ (2013): European cardiovascular magnetic resonance (EuroCMR) registry - multi national results from 57 centers in 15 countries. J Cardiovasc Magnet Reson; 15:9.

36.Cheng JM, Oemrawsingh RM, Garcia-Garcia HM, et al (2014): Relation of C-reactive protein to coronary plaque characteristics on grayscale, radiofrequency intravascular ultrasound, and cardiovascular outcome in patients with acute coronary syndrome or stable angina pectoris (from the ATHEROREMO-IVUS study). Am J Cardiol; 114:1497-503.

How to cite this article: Adel AA, Aly MA, Islam AM, Ahmed SE.The Role of Monocyte Chemoattractant Protein-1 in Diagnosis of Ischemic Heart Disease With Negative Exercise.ZUMJ 2019; 25 (2); 198-206.DOI: 10.21608/ZUMJ.2019.26921 